\title{
Prevalence of hypothyroidism in reproductive age group in rural population of Haryana and its effects on menstrual disturbances
}

\author{
Priyanka Yadav, Geetika Arora*
}

Department of Obstetrics and Gynaecology, SGT Medical College and Research Institute, Gurgaon, Haryana, India

Received: 20 November 2020

Revised: 09 January 2021

Accepted: 12 January 2021

\author{
*Correspondence: \\ Dr. Geetika Arora, \\ E-mail: drgeetikaarorabhatia@gmail.com
}

Copyright: (c) the author(s), publisher and licensee Medip Academy. This is an open-access article distributed under the terms of the Creative Commons Attribution Non-Commercial License, which permits unrestricted non-commercial use, distribution, and reproduction in any medium, provided the original work is properly cited.

\section{ABSTRACT}

Background: Menstrual disorders are a common problem in reproductive age females. These disorders may cause significant anxiety for patients and their families. Thyroid dysfunction is one of the common cause of menstrual irregularities. Aim of the study was to determine the prevalence of hypothyroidism in reproductive age group women (15-45years), describe its various modes of clinical presentation and to assess the menstrual pattern in women with hypothyroidism.

Methods: Prospective observational hospital based study during a period of 6 months (January 2020 to June 2020) on patients presenting in OPD in department of obstetrics and gynaecology, SGT medical college, hospital and research institute, Budhera, Gurgaon.

Results: Prevalence of hypothyroidism was found to be $52.6 \%$ (190 out of total 338 patients) and it increased with increasing age group. 213 patients out of total came with complains of menstrual irregularities. $49.2 \%$ with normal menstrual cycle had hypothyroidism while $60.4 \%$ presenting with irregular heavy menstrual bleeding had hypothyroidism, p value being 0.019 which was statistically significant.

Conclusions: Menstrual irregularities increase with severity of hypothyroidism. So screening for thyroid dysfunction should be included in management plan of menstrual disturbances.

Keywords: Hypothyroidism, Menstrual irregularities, Prevalence

\section{INTRODUCTION}

Menstrual disorders are a common problem among women in reproductive age group. These disorders may cause significant anxiety for patients and their families. In India, thyroid disorders are among the most common endocrine disorders. ${ }^{1}$ Thyroid disorders increase with age, and are prevalent in around $26 \%$ of premenopausal and menopausal women. ${ }^{2}$ Thyroid disorders are more common in women than men, more in older age groups.

Increased levels of TRH may raise prolactin levels, contributing to the amenorrhea associated with hypothyroidism. ${ }^{3}$ In women in their reproductive age, thyroid autoimmunity is the most prevalent cause of thyroid dysfunction. ${ }^{4,5}$ Hypothyroidism causes an increase in the levels of thyroid releasing hormone (TRH) which in turn stimulates secretion of thyroid stimulating hormone (TSH) and prolactin (PRL) and Prolactin inhibits the synthesis and secretion of gonadotrophins.

Hypothyroidism has been associated with the altered ovarian function, menstrual irregularities, subfertility, and higher (recurrent) miscarriage rates, suggesting that thyroid hormone affects female reproductive axis. ${ }^{6,7}$ In hypothyroidism, TRH induces hyperprolactinemia to alter pulsating GnRH secretion, which leads to defects or delays in the $\mathrm{LH}$ response, which again leads to defects in the luteal and anovulatory phases. Hypothyroidism also changes peripheral estrogen metabolism, reduces SHBG 
production and causes abnormal pituitary feedback. 8 Hypothyroidism also causes menorrhagia by changing the coagulation factor, namely the reduction factors VII, VIII, IX, XI. SHBG production increases in hyperthyroidism. Estrogen metabolism is altered, and the conversion of peripheral androgens to estrogen increases. Hyperthyroidism increases gonadotropin responses to $\mathrm{GnRH}$, and initial gonadotropin concentrations also often increase.

\section{METHODS}

It was a prospective observational hospital based study carried out in Department of Obstetrics and Gynaecology, SGT medical college, hospital and research institute, Budhera, Gurgaon over a period of 6 months (January 2020 to June 2020) on 338 patients.

\section{Inclusion criteria}

All women in reproductive age group between $15-45$ years of age attending OPD of obstetrics and gynaecology who gave consent of the study were included in the study.

\section{Exclusion criteria}

Pregnancy, history of thyroid cancer or thyroid related surgery, chronic smokers and alcoholics, patient with any pituitary disorders, patient with h/o corticosteroid, lithium carbonate etc and patient who did not give consent for study were excluded from the study.

All these patients were subjected for serum T3, T4 and TSH estimation along with required investigations for respective disorders.

\section{Statistical analysis}

SPSS version 21 was used for statistical analysis and calculated frequency, percentages, mean, SD and median. As a descriptive statistics for inference to compare difference between quantitative variables, Independent Ttest were used, and to compare qualitative variable, chisquare test and fisher exact test were used, wherein "P" value of less than 0.05 was considered significant.

\section{RESULTS}

A prospective observational study was conducted with 338 patients to evaluate prevalence of thyroid disorders and their effects on menstrual patterns of patients.

Table 1 shows sociodemographic profile of the patients. In our study maximum number of the females i.e. 114 $(33.7 \%)$ belonged to age group of 36-40 years followed by $>40$ year. Out of total females, 25 (75.7\%) were multiparous while 38 (11.2\%) were nulliparous. Table 2 shows distribution of participants according to their symptoms and menstrual patterns. Among 338 patients, $213(63 \%)$ had menstrual irregularities, among which 96
(28.4\%) presented with Intermenstrual bleeding with heavy flow, 61 (18\%) had intermenstrual bleeding, 54 (16\%) had heavy menstrual bleeding.

Table 1: Sociodemographic profile.

\begin{tabular}{|lll|}
\hline Parameter & Number & Percent \\
\hline Age in years & & \\
\hline Up to 25 & 29 & 8.6 \\
\hline $26-30$ & 64 & 18.9 \\
\hline $31-35$ & 41 & 12.1 \\
\hline $36-40$ & 114 & 33.7 \\
\hline$>40$ & 90 & 26.6 \\
\hline Parity & & \\
\hline Nulliparous & 38 & 11.2 \\
\hline Primigravida & 44 & 13.0 \\
\hline Multigravida & 256 & 75.7 \\
\hline Total & 338 & 100.0 \\
\hline
\end{tabular}

Table 2: Distribution of participants.

\begin{tabular}{|lll|}
\hline Symptoms & Number & Percent \\
\hline Itching per vagina & 6 & 1.8 \\
\hline Discharge per vagina & 60 & 17.8 \\
\hline Menstrual irregularities & 213 & 63.0 \\
\hline Others & 59 & 17.5 \\
\hline Menstrual pattern & & \\
\hline Regular with normal flow & 124 & 36.7 \\
\hline Heavy menstrual bleeding & 54 & 16.0 \\
\hline Intermenstrual bleeding & 61 & 18.0 \\
\hline $\begin{array}{l}\text { Intermenstrual bleeding with } \\
\text { heavy flow }\end{array}$ & 96 & 28.4 \\
\hline Post menopausal & 3 & 0.9 \\
\hline
\end{tabular}

Table 3: Prevalence of hypothyroidism.

\begin{tabular}{|lll|}
\hline Hypothyroidism & Number & Percent \\
\hline No & 148 & 43.8 \\
\hline Yes & 190 & 56.2 \\
\hline
\end{tabular}

Table 3 shows prevalence of hypothyroidism among all patients, which was seen in $190(56.2 \%)$.

Present study revealed that prevalence of hypothyroidism was increases with the increase age group and this trend was observed statistically significant (p-0.001). There was no statistical significant association found between hypothyroidism and parity (Table 4 ). Table 4 also shows association between hypothyroidism and menstrual irregularities.

Hypothyroidism was mostly found associated with Intermenstrual bleeding with heavy flow in 58 patients $(60.4 \%)$, in $38(70.4 \%)$ with heavy menstrual bleeding, in $33(54.1 \%)$ with Intermenstrual bleeding, overall $\mathrm{p}$ value being 0.019 which was statistically significant. Table 5 shows that there is no statistically significant difference was found between T3 level and hypothyroidism status 
while it was present with T4 level with mean and SD of $9.02 \pm 4.03$, with p value being 0.001 .

Table 4: Association of hypothyroidism.

\begin{tabular}{|c|c|c|c|}
\hline \multirow[b]{2}{*}{ Parameter } & \multicolumn{2}{|c|}{ Hypothyroidism } & \multirow[b]{2}{*}{$\begin{array}{l}\mathbf{P} \\
\text { value }\end{array}$} \\
\hline & $\begin{array}{l}\text { No } \\
\text { N }(\%)\end{array}$ & $\begin{array}{l}\text { Yes } \\
\mathbf{N}(\%)\end{array}$ & \\
\hline \multicolumn{4}{|l|}{ Age (in years) } \\
\hline Up to 25 & $20(69)$ & $9(31)$ & 0.001 \\
\hline $26-30$ & $38(59.4)$ & $26(40.6)$ & \\
\hline $31-35$ & $15(36.6)$ & $26(63.4)$ & \\
\hline $36-40$ & $43(37.7)$ & $71(62.3)$ & \\
\hline$>40$ & $32(35.6)$ & $58(64.4)$ & \\
\hline \multicolumn{4}{|l|}{ Parity } \\
\hline Nulliparous & $20(52.6)$ & $18(47.4)$ & 0.063 \\
\hline Primiparous & $25(56.8)$ & $19(43.2)$ & \\
\hline Multiparous & $103(40.2)$ & $153(59.8)$ & \\
\hline \multicolumn{4}{|c|}{ Menstrual history } \\
\hline $\begin{array}{l}\text { Regular with } \\
\text { normal flow }\end{array}$ & $63(50.8)$ & $61(49.2)$ & 0.019 \\
\hline $\begin{array}{l}\text { Heavy menstrual } \\
\text { bleeding }\end{array}$ & $16(29.6)$ & $38(70.4)$ & \\
\hline $\begin{array}{l}\text { Intermenstrual } \\
\text { bleeding }\end{array}$ & $28(45.9)$ & $33(54.1)$ & \\
\hline $\begin{array}{l}\text { IMB with heavy } \\
\text { flow }\end{array}$ & $38(39.6)$ & $58(60.4)$ & \\
\hline Post menopausal & $3(100)$ & $0(0)$ & \\
\hline
\end{tabular}

Table 5: Association of $\mathbf{t} 3$ and $\mathbf{t} 4$ with hypothyroidism.

\begin{tabular}{|c|c|c|c|}
\hline & \multicolumn{2}{|l|}{ Hypothyroidism } & \multirow{2}{*}{ P value } \\
\hline & No $($ mean $\pm S D)$ & Yes $($ mean \pm SD $)$ & \\
\hline T3 & $1.66 \pm 0.84$ & $1.57 \pm 1.08$ & 0.409 \\
\hline $\mathbf{T 4}$ & $2.12 \pm 1.02$ & $9.02 \pm 4.03$ & 0.001 \\
\hline
\end{tabular}

\section{DISCUSSION}

Thyroid disorders in general and among which hypothyroidism is one of the common causes of menstrual disorders in women. Thyroid status among women influence menarche, puberty, menstruation, fertility, reproductive and postmenopausal years. The connection between thyroid hormone levels and the menstrual cycle is mainly mediated by thyrotropin releasing hormone (TRH), which has a direct effect on the ovary and abnormal thyroid function can alter levels of sex hormone binding globulin, prolactin, and gonadotropin releasing hormone, contributing to menstrual dysfunction.

In a study by Pahwa et al among 100 dysfunctional uterine bleeding patients, the commonest menstrual complaint was menorrhagia constituting $50 \%$ followed by polymenorrhoea (19\%), menometrorrhagia (18\%), metropathia haemorrhagica $(7 \%)$ and $6 \%$ had irregular bleeding with uncertain pattern. ${ }^{9}$ While in present study intermenstrual bleeding with heavy flow was the most common menstrual complaint. In a study among dysfunctional uterine bleeding patients,

Sharma et al, reported hypothyroidism and hyperthyroidism in $22 \%$ and $14 \%$ patients respectively. ${ }^{10}$ In this study, hypothyroidism prevalence was seen in 190 patients $(56.2 \%)$. Studies show prevalence of subclinical hypothyroidism as $4 \%$ to $8 \%$ in general population, and upto $15 \%$ to $18 \%$ in women who are over 60 years of age.

Novak says both hypothyroidism and hyperthyroidism can be associated with abnormal menstrual bleeding. ${ }^{11}$ With hypothyroidism, menstrual abnormalities, including menorrhagia are common. Thyroid hormones affect menstrual cycle and both hyperthyroidism and hypothyroidism may result in menstrual disturbances. Thyroid function should be evaluated in all cases of menorrhagia.

Pilli et al, concluded menorrhagia as the commonest type of bleeding (34\%), profuse bleeding following amenorrhoea in $14 \%$ and polymenorrhoea in $11 \%$ as least common in contrast to the present study where intermenstrual bleeding with heavy flow was most common. ${ }^{12}$

\section{Limitation}

This study had a small sample size. This limited sample size prevented thorough investigation of potential effect measure modification by several characteristics that are known to affect menstrual cycle function parameters. Secondly, although particular thyroid hormone levels were associated with certain menstrual cycle patterns, it is possible that the associations are not independent because of negative feedback loop of thyroid resulting in functional relationships between hormones.

\section{CONCLUSION}

Present study finds high prevalence of hypothyroidism in rural population of Haryana, and its significant effects on menstrual cycle. Thus it may be beneficial to screen menstrual disorder patients for thyroid dysfunction especially to rule out thyroid disorder as a potential etiological agent for menstrual disturbance. The prevalence of subclinical hypothyroidism in patients with menstrual disorders emphasizes the need to detect the hypothyroidism at this stage, so that treatment can be initiated and progression to overt disease be slowed down as a part of management of menstrual disorders.

\section{ACKNOWLEDGMENTS}

Authors would like to express their deep and sincere gratitude to Dr. S P S Kochar, Professor and head of department of Obstetrics and Gynaecology, SGT Medical College and Research Institute, for giving them opportunity to do the research and providing invaluable guidance. 
Funding: No funding sources

Conflict of interest: None declared

Ethical approval: The study was approved by the Institutional Ethics Committee

\section{REFERENCES}

1. Kochupillai N. Clinical endocrinology in India. Curr Sci. 2000;79:1061-7.

2. Hollowell JG, Staehling NW, Flanders WD. Serum TSH, T4, and thyroid antibodies in the United States population (1988 to 1994): National Health and Nutrition Examination Survey (NHANES III). J Clin Endocrinol Metab. 2002;87(2):489-99.

3. Stern L. Thyroid dysfunction and the menstrual cycle. Clinical Advisor Forum. 2009.

4. Hollowell JG, Staehling NW, Flanders WD, Hannon WH, Gunter EW, Spencer CA, et al. Serum TSH, T (4), and thyroid antibodies in the United States population (1988 to 1994): National Health and Nutrition Examination Survey (NHANES III). J Clin Endocrinol Metab. 2002;87:489-99.

5. Vanderpump MP, Tunbridge WM, French JM, Appleton D, Bates D, Clark F, et al. The incidence of thyroid disorders in the community: a twenty-year follow-up of the Whickham survey. Clin Endocrinol. 1995;43:55-68.

6. Krassas GE, Papadopoulou F, Tziomalos K, Zeginiadou T, Pontikides N. Hypothyroidism has an adverse effect on human spermatogenesis: a prospective, controlled study. Thyroid. 2008;18:1255-9.

7. Boogaard E, Vissenberg R, Land JA, Wely M, Post JA, Goddijn M, et al. Significance of (sub) clinical thyroid dysfunction and thyroid autoimmunity before conception and in early pregnancy: a systematic review. Hum Reprod Update. 2011;17:605-19.

8. Shah MS, Patange RP. A study of correlation between thyroid disorders and menstrual disorders in reproductive age group. IJRPS. 2020;11(3):3183-90.

9. Pahwa S, Shailja G, Jasmine K. Thyroid dysfunction in dysfunctional uterine bleeding. J Adv Res Bio Sci. 2013;5(1):78-83.

10. Sharma N, Sharma A. Thyroid profile in menstrual disorders. JK Science. 2012;14(1):14-7.

11. Hillard PJA. Benign diseases of the female reproductive tract. Symptoms and Signs. Jonathan S. Berek. Novak's Gynaecology. $13^{\text {th }}$ edition. Philadelphia USA. 2002:351-368.

12. Pilli GS, Sethi B, Dhaded AV, Mathur PR. Dysfunctional uterine bleeding. J Obstet Gynecol India. 2002;52(3):87-9.

Cite this article as: Yadav P, Arora G. Prevalence of hypothyroidism in reproductive age group in rural population of Haryana and its effects on menstrual disturbances. Int J Reprod Contracept Obstet Gynecol 2021;10:567-70. 